\title{
Discipline, Electoral Rules and Defection in the Bundestag, 1983-94
}

\author{
MICHAEL BECHER and ULRICH SIEBERER
}

\begin{abstract}
This article examines how party discipline and legislators' individual policy goals induced by electoral rules influence the likelihood of defections from the party line in the Bundestag. Using a new indicator based on legislators' explanations of their voting behaviour we find strong evidence that discipline, not policy cohesiveness alone, drives party unity. In particular, the allocation of offices by the party leadership significantly affects legislators' propensity to defect from the position of their party. First, holding an executive office reduces legislators' probability to defect by approximately 19 per cent. Second, parliamentary office also reduces legislators' probability to defect, although the effect is smaller. District legislators are not generally more prone to defect, but their propensity to defect increases if electoral competition increases.
\end{abstract}

\section{INTRODUCTION}

Observed party unity in the German Bundestag as well as in other parliamentary democracies is generally high, but we know little about its sources. In this article, we study why some legislators are more likely than others to defect from the position of their party. In particular, we examine how discipline and electoral rules impact on legislators' propensity to defect from their party's position. Previous national and cross-national studies relied on roll-call votes to measure legislators' behavioural conformity with the party line and, in the aggregate, the resulting unity of party voting. ${ }^{1}$ We introduce a complementary indicator based on legislators' public explanation of their voting decision (Erklärungen zur Abstimmung). These explanations are a valuable resource for studying individual voting behaviour that is not restricted to recorded votes and has been largely ignored by previous research. ${ }^{2}$

Legislative studies, especially in parliamentary systems of government, often treat parties as unitary actors. While this assumption is plausible for many research questions, party unity is not naturally given but results from the decisions of individual legislators to follow the party line or defect from it. We aim to explore the mechanisms that account for varying patterns of defection among legislators. Theoretically, observed party unity can be caused by countervailing factors such as homogenous policy preferences or the use of discipline by the party leadership. Our data on deviant or defecting (we use both terms interchangeably) legislators allows us to disentangle some of these effects.

Our empirical analysis supports the view that the high party unity in the Bundestag at least partly results from discipline rather than shared preferences. This conclusion is 
based on the finding that legislators in executive or parliamentary office are substantially less likely than backbenchers to defect from the position of their party in legislative decision-making. The results also show that government legislators are less inclined to defect than opposition legislators when controlling for office variables. In contrast with theoretical expectations, our evidence does not support the argument that district legislators are generally more likely to defect than legislators elected from a party list. If anything, district legislators are less prone to defect. Moreover, the effect of electoral rules is conditioned by electoral competition. As district races become closer, legislators elected in these districts become more likely to defect.

The next section reviews theoretical explanations of individual defection and party unity found in the literature and derives hypotheses concerning the determinants of legislators' propensity to toe the party line. Afterwards, we describe the data set and present empirical results. The concluding remarks sketch ways to further advance the analysis of deviant explanations of votes and party unity in the Bundestag.

\section{EXPLANATIONS OF DEFECTION AND PARTY UNITY}

Although legislators in parliamentary democracies usually vote along party lines, recent models of legislative behaviour stress that party unity cannot be taken for granted. Parliamentary parties are collective actors, and the interests of their constituent units, individual legislators, may diverge. Carey argues that observed levels of unity can be caused by three different factors: cohesiveness, discipline, or agenda control. ${ }^{3}$ Cohesiveness refers to the degree of policy agreement among legislators. Discipline denotes the use of selective incentives by the party leadership to achieve party unity despite disagreements over policy. Agenda control entails the ability of the party leadership to avoid votes on divisive issues. The theoretical and empirical literature tries to disentangle these alternative sources of party unity. This article aims to contribute to this task focusing on the micro level (i.e., defection).

In Carey's theoretical framework, party discipline is primarily linked to government participation. Accordingly, leaders of government parties in parliamentary democracies, in which the cabinet can be brought down by a vote of no confidence in parliament, should have the motivation and resources to impose discipline on party members and thus achieve a higher level of party unity. If policy disagreements exist within parties, maintaining a stable government requires discipline. Government participation allows party leaders to provide office and policy benefits to loyal legislators and withhold them from those defecting from the party line. These carrots and sticks are not available to opposition parties. Thus, legislators of governing parties should be less likely to defect from the position of their party, even when they disagree with it, than legislators from the opposition. ${ }^{4}$ On the aggregate level, however, Saalfeld's comprehensive study of party unity in the Bundestag between 1949 and 1990 found no support for the disciplining force of government participation. Contrary to expectations, government participation decreases voting unity. ${ }^{5}$ As a corollary, legislators' propensity to defect should also vary within parties according to the distribution of spoils: legislators in government and members of the parliamentary party leadership, both within governing and opposition parties, should be more disciplined than backbenchers. There is some evidence that during Adenauer's chancellorship, 
ministers and party whips within the CDU/CSU were less likely to defect than backbenchers, but this hypothesis has not been confronted with more recent data. ${ }^{6}$

Cohesion, the second theoretical source of party unity, refers to the homogeneity of policy preferences within a party. On the micro level, holding discipline and agenda control constant, legislators' propensity to defect should be positively related to the distance between their preferred policy and the policy position of their party. Policy disagreement is difficult to measure directly, but much of the scholarship on electoral systems argues that formal electoral rules shape legislators' policy preferences because they induce different strategies of how legislators can reach their most proximate goal: re-election. ${ }^{7}$ According to Norris, for example, the incentives of legislators to build a personal reputation beyond their party's brand name, based on constituency service and policy responsiveness to local demands, are greater for legislators elected in single-member districts than for those elected on closed party lists. ${ }^{8}$ Building a personal vote based on geographical representation may lead to policy disagreement with the party position.

Mixed electoral systems such as the German one are particularly interesting cases because they allow researchers to study the effects of formal institutions while holding country-specific factors constant. ${ }^{9}$ German electoral law establishes two distinct types of legislators: those elected by plurality in single-member districts (referred to as district legislators) and those who gain a Bundestag seat through closed party lists elected by proportional representation (they will be called party-list legislators). As the German system is compensatory, a party's district seats are counted as part of its proportional seat share. ${ }^{10}$ Norris' argument implies that we should expect district legislators to be less willing to toe the party line as they may have electoral motives to differentiate their position from that of their party. Contrary to theoretical expectations, a study of deviant votes in the CDU/CSU during the second Bundestag (1953-57) found that district legislators were less likely to deviate from their party's position than party-list legislators. ${ }^{11}$ These early findings, however, were not confirmed in later analyses that found no significant relationship between legislator type and deviating voting behaviour until the mid-1960s. ${ }^{12}$

More generally, the traditional view in the empirical literature on the Bundestag is that district legislators do not significantly differ in their behaviour from party-list legislators. ${ }^{13}$ This similarity is said to result from the high number of double candidacies, that is, legislators running both in a district and on a party list. As a consequence, behavioural incentives are blurred. Recent studies, however, have shown that district legislators place more emphasis on the representation of local interests than party-list legislators, and that district legislators are more likely to select committees that deal with local (i.e., pork-barrel) issues. ${ }^{14}$ Moreover, campaign strategies of district candidates differ from those of party-list candidates. ${ }^{15}$ Empirical evidence is scarce, however, on whether electoral rules matter for legislative behaviour such as legislators' propensity to defect from the party line in Bundestag voting in the more recent past.

Third, high party unity may result from party leaders' control of the legislative agenda, which allows them to avoid votes that could split the party. ${ }^{16}$ German government parties are rather weak in this respect. They cannot keep the opposition from forcing a plenary vote even on divisive issues. Compared to cases with strong 
government agenda control, such as the United Kingdom, formal agenda powers do not vary extensively between governing and opposition parties in the German system. ${ }^{17}$

This section has presented a number of hypotheses on the determinants of legislators' propensity to defect from the party line that are tied to distinct theoretical mechanisms. Before we empirically assess these hypotheses, we introduce our indicator of defection based on explanations of voting behaviour.

\section{MEASURING DEFECTION WITH EXPLANATIONS OF VOTES}

After a proposal has been debated and before legislators vote on its fate, Bundestag rules allow legislators to give a short oral or written explanation of their voting decision. ${ }^{18}$ Verbal statements in front of the Bundestag may be up to five minutes long. Legislators can also make a joint statement concerning their voting decision. We treated joint statements as equivalent to separate statements by each legislator who signed the explanation. In contrast to speeches in plenary debates, legislators' opportunity to state their voting decision is neither capped nor distributed by party leaders. Thus, these explanations allow us to tap into individual dissent that will usually not be voiced in plenary debates where the party leadership controls who speaks for the party. In addition, they allow us to include non-recorded votes which are far more representative of everyday business in the Bundestag than roll-call votes, on which all currently available studies of party unity rely. Explanations of votes are archived in the official records of the Bundestag.

Based on a list of all explanations of votes in Schindler's data handbook, ${ }^{19}$ we identified and coded the content of legislators' explanations of votes from the 10th to the 12th Bundestag (1983-94). Unfortunately, the list was not extended beyond 1994. Before 1983, explanations of votes were rare, and before 1970 they were limited to roll-call votes. As a consequence, we restrict our study to the period between 1983 and 1994.

For each explanation, we coded whether a legislator goes along with or defects from the party line. The party line was determined by noting the position of party leaders in the plenary debate and, if available, reported voting results. A legislator defects when he or she announces to vote contrary to the party position. In line with previous studies of roll-call voting, abstention when the party does not abstain or voting when the party abstains is also considered a defection. ${ }^{20}$ Voicing reservations but nonetheless following the party line is not considered a deviation. Free votes on which the party did not articulate a party line but allowed its members to vote according to their conscience are excluded from the analysis.

We counted the number of deviant explanations of votes for each legislator in each legislative period under study. The data set contains observations for all legislators in the Bundestag at the beginning of the legislative periods. Thus, we do not include legislators that enter the Bundestag later during a legislative term. Also, we exclude the East German delegates elected by the Volkskammer who joined the Bundestag for a few weeks from re-unification to the Bundestag election in December 1990. In the 11th and 12th Bundestag, delegates from West Berlin were dropped because they did not have voting rights. 
TABLE 1

FREQUENCY OF DEVIANT EXPLANATIONS OF VOTES IN THE BUNDESTAG

\begin{tabular}{lrrr}
\hline & \multicolumn{3}{c}{ Legislators } \\
\cline { 2 - 4 } $\begin{array}{l}\text { Number of deviant explanations } \\
\text { per legislative period }\end{array}$ & \multicolumn{1}{c}{$\mathbf{N}$} & $\%$ & Cum. \\
\hline 0 & 1,217 & 73.36 & 73.36 \\
1 & 301 & 18.14 & 91.50 \\
2 & 96 & 5.79 & 97.29 \\
3 & 27 & 1.63 & 98.92 \\
4 & 9 & 0.54 & 99.46 \\
5 & 4 & 0.24 & 99.70 \\
6 & 1 & 0.06 & 99.76 \\
7 & 1 & 0.06 & 99.82 \\
8 & 1 & 0.06 & 99.88 \\
9 & 1 & 0.06 & 99.94 \\
11 & 1 & 0.06 & 100.00 \\
Total & 1,659 & 100.00 & \\
\hline
\end{tabular}

Note: observations are pooled for the 10th, 11th, and 12th Bundestag.

Table 1 shows the frequency of deviant explanations of votes for all 1,659 legislators in the data set, pooled across legislative periods. ${ }^{21}$ More than 70 per cent of all legislators never deviate from the line of their party. This is consistent with the conventional view that party unity in the Bundestag is high. About 18 per cent deviate once per legislative period and only very few legislators deviate more than once. Thus, for the following analysis we simply consider a binary dependent variable. Defection is coded as 1 if a legislator deviates from the party line at least once during a legislative term and 0 otherwise. The purpose of this redefinition is to ease the presentation of the results. The substantive findings presented in the next section are robust if the original count variable is used.

\section{RESULTS}

\section{Description}

Our empirical analysis proceeds in two steps. First, we describe the bivariate relationship between defection from the party line and potential explanatory variables related to party discipline and policy disagreement. Second, we assess the robustness of the initial findings using multiple regression analysis. Since legislators are not randomly assigned values on the variables of interest, we control for some of the factors that may lead to spurious relationships in a bivariate analysis.

Table 2 shows that the percentage of defections among SPD legislators is higher than among any other party during the years from 1983 to 1994. In the CDU/CSU defections are much less common than in the FDP. The two smallest parties at that time, the Greens and the PDS, exhibit the lowest percentage of defections. However, data for the PDS are only available from 1990 onwards, when it first entered the Bundestag and it had few legislators.

As we pointed out, the theoretical literature argues that the leadership of government parties is more willing and more able to discipline its members than opposition 
TABLE 2

DEFECTING LEGISLATORS BY PARLIAMENTARY PARTY

\begin{tabular}{lcccr}
\hline & \multicolumn{3}{c}{ Legislator defects once or more } \\
\cline { 2 - 4 } Parliamentary party & No \% & Yes \% & Total \% & N \\
\hline CDU/CSU & 80.2 & 19.8 & 100.0 & 786 \\
SPD & 64.7 & 35.3 & 100.0 & 620 \\
FDP & 66.0 & 34.0 & 100.0 & 159 \\
Greens & 84.4 & 15.6 & 100.0 & 77 \\
PDS & 94.1 & 5.9 & 100.0 & 17 \\
Total & 73.4 & 26.6 & 100.0 & 1,659 \\
\hline
\end{tabular}

Note: observations are pooled for the 10th, 11th, and 12th Bundestag.

leaders. Government parties in particular can use office appointments to reward loyal legislators and punish those who defect. We construct an executive office dummy variable that is coded 1 if a legislator holds the office of cabinet minister or junior minister (parlamentarische Staatssekretäre) during a legislative period and 0 otherwise. Following the same logic, a variable for parliamentary office is constructed. The set of parliamentary offices comprises the president and vice presidents of the Bundestag, and all committee chairpersons and deputy chairpersons. Furthermore, the set includes the following party offices in the Bundestag: party chairpersons and their deputies, whips (parlamentarische Geschäftsführer), and the heads of working groups within the parliamentary party. ${ }^{22}$ These officeholders can be considered members of the (extended) parliamentary party leadership, and these positions, contrary to executive offices, are also relevant for opposition parties. Legislators not holding any of these offices are considered backbenchers. Following the logic of the discipline argument, the expectation is that legislators holding executive or parliamentary offices are less likely to defect than backbenchers. ${ }^{23}$

As expected from the discipline argument, Table 3 shows that government legislators are indeed less prone to defect than members of opposition parties. The difference is about 10 percentage points and statistically significant in a Chi ${ }^{2}$ test. Moreover, executive officeholders are much more disciplined than those without such appointments. The percentage difference is more than twice as large as for the government party variable and significant. Finally, the percentage of defections for legislators with a parliamentary office is significantly smaller than for those of backbenchers. This difference, however, is less pronounced than for the two government variables.

Contrary to the theoretical expectations in the electoral systems literature, Table 4 shows that district legislators do not defect from the position of their party more readily than party-list legislators. The tabulation even suggests the opposite, with a statistically significant difference of almost 10 percentage points. This result also conflicts with the assertion that the two types of legislators do not differ in their behaviour.

In the next step multiple regression analysis is used to assess the robustness of the initial findings. Moreover, we will go beyond the simple institutional dichotomy between district and party-list legislators and pay attention to the competitiveness of district races. 
TABLE 3

GOVERNMENT PARTICIPATION, OFFICE, AND DEFECTING LEGISLATORS

\begin{tabular}{lcccrr}
\hline & \multicolumn{4}{c}{ Legislator Defects Once or More } \\
\cline { 2 - 5 } & No \% & Yes \% & Total \% & Chi $^{\mathbf{2}}$ & N \\
\hline Governing party & & & & & \\
No & 67.5 & 32.5 & 100.0 & $21.95^{* * *}$ & 714 \\
Yes & 77.8 & 22.2 & 100.0 & & 945 \\
Executive office & & & & $34.38^{* * *}$ & 1,496 \\
No & 71.3 & 28.7 & 100.0 & & 163 \\
Yes & 92.6 & 7.4 & 100.0 & & 1,210 \\
Parliamentary & office & 71.4 & 28.6 & 100.0 & 449 \\
No & 78.6 & 21.4 & 100.0 & \\
Yes & 73.4 & 26.6 & 100.0 & \\
Total & 1,217 & 442 & 1,659 & \\
N & & & & & \\
\hline
\end{tabular}

Note: observations are pooled for the 10th, 11th, and 12th Bundestag.

${ }^{*} p<0.05,{ }^{* *} p<0.01,{ }^{* * *} p<0.001$.

TABLE 4

ELECTORAL RULES AND DEFECTING LEGISLATORS

\begin{tabular}{|c|c|c|c|c|c|}
\hline & \multicolumn{4}{|c|}{ Legislator defects once or more } & \multirow[b]{2}{*}{$\mathbf{N}$} \\
\hline & No $\%$ & Yes \% & Total \% & $\mathrm{Chi}^{2}$ & \\
\hline \multicolumn{6}{|c|}{ District legislator } \\
\hline No & 68.5 & 31.5 & 100.0 & $20.27^{* * *}$ & 835 \\
\hline Yes & 78.3 & 21.7 & 100.0 & & 824 \\
\hline Total & 73.4 & 26.6 & 100.0 & & 1,659 \\
\hline
\end{tabular}

Note: observations are pooled for the 10th, 11th, and 12th Bundestag.

${ }^{*} p<0.05,{ }^{* *} p<0.01,{ }^{* *} p<0.001$.

\section{Regression Analysis}

Table 5 summarises the results from logit regressions. ${ }^{24}$ The cell entries show the marginal change in the predicted probability that a legislator deviates at least once from the line of his or her party during a legislative term for each explanatory variable, holding all other variables constant at their mean. For binary explanatory variables (i.e., most of our variables of interest) the effect equals the predicted change in the probability of defection when the variable is changed from 0 to 1 .

Before we discuss the results, note that we estimated two different empirical specifications. Model 1 contains the previously discussed explanatory variables related to discipline (dummies for government participation, executive office, and parliamentary office), and policy disagreement induced by electoral rules (a dummy for district legislators). An additional electoral rules variable is entered to capture the more complex incentive structure created by differences in electoral competition between districts.

More precisely, we have created a variable to capture the electoral competitiveness of a legislator's seat, with higher values indicating a higher degree of competition. ${ }^{25}$ 
DETERMINANTS OF LEGISLATIVE DEFECTION IN THE BUNDESTAG (1983-1994)

\begin{tabular}{|c|c|c|c|}
\hline & Hypothesis & Model 1 & Model 2 \\
\hline \multicolumn{4}{|l|}{ Discipline } \\
\hline Governing party ${ }^{\mathrm{d}}$ & - & $-0.0351(0.0228)$ & $-0.0901^{* * *}(0.0251)$ \\
\hline Executive office $^{\mathrm{d}}$ & - & $-0.200^{* * *}(0.0257)$ & $-0.185^{* * *}(0.0226)$ \\
\hline Parliamentary office $^{\mathrm{d}}$ & - & $-0.0821^{* * *}(0.0225)$ & $-0.0761^{* * *}(0.0227)$ \\
\hline \multicolumn{4}{|l|}{ Policy disagreement } \\
\hline District legislator ${ }^{\mathrm{d}}$ & + & $-0.0927^{* * *}(0.0225)$ & $-0.0845^{* * *}(0.0240)$ \\
\hline $\begin{array}{l}\text { Electoral competitiveness } \\
\quad(\min =0, \max =10)\end{array}$ & + & $0.0498^{* * *}(0.0109)$ & $0.0386^{* * *}(0.0101)$ \\
\hline \multicolumn{4}{|l|}{ Controls } \\
\hline Seniority $(\min =0, \max =11)$ & & & $-0.000548(0.00624)$ \\
\hline $\mathrm{FDP}^{\mathrm{d}}$ & & & $0.0713(0.0465)$ \\
\hline Greens ${ }^{\mathrm{d}}$ & & & $-0.115^{* * *}(0.0340)$ \\
\hline $\mathrm{PDS}^{\mathrm{d}}$ & & & $-0.208^{* * *}(0.0195)$ \\
\hline Dummy for 10th BT $(1983-87)^{\mathrm{d}}$ & & & $-0.279^{* * *}(0.0184)$ \\
\hline Dummy for 11th BT $(1987-90)^{d}$ & & & $-0.143^{* * *}(0.0199)$ \\
\hline Observations & & 1659 & 1659 \\
\hline Classified correctly & & 0.738 & 0.756 \\
\hline
\end{tabular}

Dependent variable: defection $(1=$ one or more defecting explanations, $0=$ none $)$.

Cell entries are marginal effects (with all other variables held constant at their mean) from logit regression; robust standard errors in parentheses.

${ }^{\mathrm{d}}$ for discrete change of dummy variable from $0=$ no to $1=$ yes.

${ }^{*} p<0.05,{ }^{* *} p<0.01,{ }^{* * *} p<0.001$.

For district legislators, the indicator is the inverse of the margin of district votes (Erststimmen) between the winner and second-placed candidate in the last election. For example, if the district vote margin is 5 percentage points, the indicator takes the value $1 / 5$. For extremely close races with margins less than 1 percentage point, the indicator is greater than 1. In highly competitive districts, district legislators should face strong incentives to be responsive to local demands, possibly also against their party's position. Thus, the expectation is that district legislators become more willing to defect in order to build a personal vote as interparty electoral competition for their district seat increases. In contrast, party-list legislators only depend on their party's brand name for re-election. For them, competitiveness is $0 .{ }^{26}$

Model 2 adds the following control variables: seniority, defined as the number of legislative terms served in the Bundestag, and dummies for parties and legislative periods. Two arguments forwarded in the literature imply that legislators' propensity to deviate from their party might decline as legislative experience increases. First, socialisation increases policy coherence or at least willingness to follow the party line. Second, seniority tends to co-vary with influence over policy. For both reasons, senior legislators might be less likely to deviate than their more junior colleagues. ${ }^{27}$

The party dummies control for party-specific differences in defection. Such factors may be party ideology, individualistic or collectivist notions of representation, the importance and influence of intra-party groups, or the skills of party leaders. Only three party dummies are entered to avoid perfect collinearity between the government 
dummy and the party dummies. In the period under study, there is no variance of government parties. During the whole period, a coalition of CDU/CSU and FDP, led by Helmut Kohl, formed the cabinet. As a consequence, the data do not allow us to clearly distinguish between the effect of government and the effect of party-specific factors. However, our office variables vary within government parties and thus allow us to better assess the discipline hypothesis. Finally, the legislative period dummies capture differences that may result from time-specific differences in the political agenda. Most important, perhaps, our period of investigation includes some consequential and controversial decisions in the context of German reunification during the 11th Bundestag (1987-90).

Both statistical models in Table 5 indicate that the discipline variables significantly impact on defection when other variables are controlled for. Among the three variables, executive office has the strongest effect. More precisely, Model 2 in Table 5 suggests that, keeping other things equal at their mean, holding an executive office decreases a legislator's probability to defect at least once by roughly 19 per cent, plus or minus two percentage points. Parliamentary office also reduces the probability of defection by about 8 per cent. The impact of government participation is only borderline significant at the 5 per cent level in Model 1 . However, the effect more than doubles in size and becomes statistically significant when all controls are entered in Model 2. In this specification, being a member of a government party reduces the likelihood of defection by 9 per cent.

These results are in line with our descriptive findings and support the argument that discipline drives low levels of voting dissent in government parties. It is important, however, to note that we have not directly observed the use of sanctions in response to loyal or disloyal voting behaviour. Instead, we rely on the argument that the ability to allocate offices and use other carrots and sticks that are mainly available to governing parties makes the threat of sanctions by party leaders more credible. Credible sanctions, in turn, should lower legislators' propensity to deviate from their party line. $^{28}$

The evidence concerning policy disagreement as captured by electoral rules is mixed. In line with the bivariate findings, the regression estimates suggest that district legislators are less likely to defect from their party line than party-list legislators. This, again, is contrary to conventional theoretical arguments. Electoral competitiveness, by contrast, shows the hypothesised effect. District legislators are more likely to defect if electoral competitiveness increases. This lends support to a more fine-grained view on how electoral rules matter for legislative defection. From this perspective, incentives to defect from the party line, presumably to satisfy local demands, are particularly relevant in marginal districts. One needs to keep in mind, however, that only a small fraction of the districts in the data set are highly competitive. In nearly 90 per cent of all cases the vote margin in the district exceeds 5 percentage points, which translates into a competitiveness score of less than $0.2 .^{29}$

Some of the control variables, that is the period dummies and the variables for the Greens and the PDS, are statistically significant. This indicates that time- and partyspecific factors also influence legislators' propensity to toe the party line. The effects of the office and electoral rule variables remain substantively unchanged, though, when these controls are entered into the model. 


\section{CONCLUSION}

This article has examined how two distinct theoretical mechanisms, discipline and policy disagreement, affect individual voting behaviour in the Bundestag. Based on the literature, we argue that government participation in general and the allocation of executive and parliamentary offices in particular are linked to discipline. Also, we argue that electoral rules influence district legislators' motivation to build a personal vote based on geographical concerns, which may lead to policy disagreement with the party line.

Using previously ignored data on legislators' explanations of their voting decisions for the period between 1983 and 1994, we find that discipline variables indeed are significant and substantively relevant determinants of legislators' defection from the party line. This supports the view that discipline is a driving force behind observed party unity. The evidence on the impact of electoral rules on defection is mixed. Contrary to theoretical expectations, district legislators are more likely to toe the party line when compared to their colleagues elected via party lists. Nonetheless, greater competitiveness of district seats increases the propensity of the respective district legislators to deviate from the party line. Taken together, these findings imply that the incentives deriving from formal electoral rules should be linked more systematically with the actor constellation and competitive pressures in individual district races. Such a focus could reconcile some of the competing views and findings on the relevance of differences between district and party-list legislators in the Bundestag.

There are three caveats to bear in mind when assessing our findings that point to perspectives for the future study of defection and party unity in the Bundestag. First, our indicator captures only declared defections from the party line. It ignores those that are not explained in public. Thus, it is possible that we only observe the tip of the iceberg. We can neither rule out this possibility nor assess its frequency. However, an undeclared defection is politically less relevant because it neither hurts the party's success in winning legislative votes nor sends a signal to voters or other political actors.

Second, we cannot completely disentangle the effects of government participation from party effects, because the CDU/CSU and the FDP formed the governing coalition over the entire period under study. An extension of the dataset to more recent periods could help us to better separate these effects by including different governing constellations such as the red-green coalition or the current grand coalition. Fortunately, this problem does not affect our more detailed discipline-related hypotheses based on the effects of holding executive or parliamentary office, as these variables differ within the governing parties.

Finally, our theoretical argument about the relevance of electoral rules for policy disagreement focused on divergent preferences resulting from local constituency demands. Explanations of votes provide cursory qualitative evidence that legislators justify their defections on the grounds of local interest representation. Nonetheless, we also find explanations referring to ideologically defined intra-party factions. Thus, intra-party politics not directly tied to constituency demands offers a complementary and possibly competing explanation for observed defection, especially when larger groups of legislators diverge from the party line on a specific vote. 
It would therefore be worthwhile to analyse the content of explanations of votes in more detail to see what audiences (local constituencies, intra-party groups, interest groups, etc.) legislators address.

\section{NOTES}

We are grateful for comments and suggestions by Philip Manow, Thomas Zittel, and the participants of the workshops on 'Mixed Electoral System and Political Representation' and 'Legislative Data' at the Max Planck Institute for the Study of Societies in Cologne. We thank Dominic Heinz for providing us with data on legislators' seniority and executive and parliamentary offices.

1. For recent times-series cross-section studies see John M. Carey, 'Competing Principals, Political Institutions, and Party Unit in Legislative Voting', American Journal of Political Science 51/1 (2007), pp.92-107; Ulrich Sieberer, 'Party Unity in Parliamentary Democracies: A Comparative Analysis', Journal of Legislative Studies 12/2 (2006), pp.150-78. For a comprehensive longitudinal study of the Bundestag see Thomas Saalfeld, Parteisoldaten und Rebellen (Opladen: Leske + Budrich, 1995). For early studies of the Bundestag see George L. Rueckert and Wilder Crane, 'CDU Deviancy in the German Bundestag', Journal of Politics 24/3 (1962), pp.477-88; Frank H. Dishaw, 'Roll Call Vote Deviancy of the CDU/CSU Fraktion in the West German Bundestag', Sozialwissenschaftliches Jahrbuch für Politik 2 (1971), pp.539-61.

2. Some studies note that explanations of votes are an indicator for intra-party preference heterogeneity, but do not analyse them systematically: Saalfeld, Parteisoldaten und Rebellen, p.181; Klaus von Beyme, Der Gesetzgeber (Opladen: Westdeutscher Verlag, 1997), p.274.

3. Carey, 'Competing Principals', p.93.

4. Ibid., p.95; Saalfeld, Parteisoldaten und Rebellen, p.271.

5. Saalfeld, Parteisoldaten und Rebellen, pp.275-9.

6. Dishaw, 'Roll Call Vote Deviancy', p.546.

7. Legislators may pursue other goals such as office and policy, but re-election is a necessary precondition for reaching those and can therefore be modelled as the most proximate objective; see David R. Mayhew, Congress. The Electoral Connection (New Haven, CT: Yale University Press, 1974).

8. Pippa Norris, 'Voting Rules and Political Behaviour', Electoral Engineering (Cambridge: Cambridge University Press, 2004), p.12. For a more detailed ranking of institutional incentives to build a personal vote see John M. Carey and Matthew Soberg Shugart, 'Incentives to Cultivate a Personal Vote: A Rank Ordering of Electoral Formulas', Electoral Studies 14/4 (1995), pp.417-39.

9. Norris, Electoral Engineering, p.237.

10. For a more detailed discussion of mixed-electoral system, see André Kaiser, 'Gemischte Wahlsysteme', Zeitschrift für Politikwissenschaft 12/4 (2002), pp.1545-71. On the origins of the German electoral system, see Kathleen Bawn, 'The Logic of Institutional Preferences: German Electoral Law as a Social Choice Outcome', American Journal of Political Science 37/4 (1993), pp.965-89.

11. Rueckert and Crane, 'CDU Deviancy', p.449.

12. Dishaw, 'Roll Call Vote Deviancy', p.543.

13. Dieter Nohlen and Rainer-Olaf Schultze, Wahlsysteme der Welt (München: Piper, 1978), p.305; Wolfgang Ismayr, Der Deutsche Bundestag im politischen System der Bundesrepublik Deutschland (Opladen: Leske + Budrich, 2000), pp.85-91.

14. Hans-Dieter Klingemann and Bernhard Wessels, 'The Political Consequences of Germany's MixedMember System: Personalization at the Grass Roots?', in Matthew Soberg Shugart and Martin P. Wattenberg (eds.), Mixed-Member Electoral Systems: The Best of Both Worlds? (Oxford: Oxford University Press, 2001), pp.279-96; Thomas Stratmann and Martin Baur, 'Plurality Rule, Proportional Representation, and the German Bundestag: How Incentives to Pork-Barrel Differ across Electoral Systems', American Journal of Political Science 46/3 (2002), pp.506-14.

15. Thomas Zittel and Thomas Gschwend, 'Individualisierte Wahlkämpfe im Wahlkreis: Eine Analyse am Beispiel des Bundestagswahlkampfes von 2005', Politische Vierteljahresschrift 48/2 (2007), pp.293-321.

16. Carey, 'Competing Principals'; Gary W. Cox and Mathew D. McCubbins, Setting the Agenda. Responsible Party Government in the U.S. House of Representatives (Cambridge: Cambridge University Press, 2005).

17. Ulrich Sieberer, 'Agenda Setting in the German Bundestag: A Weak Government in a Consensus Democracy', German Politics 15/1 (2006), pp.49-72. From our view, therefore, the empirical finding that government parties, in contrast to opposition parties, hardly ever lose plenary votes is 
better attributed to high party unity deriving from sources other than agenda control. For the alternative argument based on agenda control see William M. Chandler, Gary W. Cox and Mathew D. McCubbins, 'Agenda Control in the Bundestag, 1980-2002', German Politics 15/1 (2006), pp.27-48.

18. Currently, $\S 31$ (1) of the parliamentary rules (Geschäftsordnung des Bundestages) regulates the use of explanations of votes.

19. Peter Schindler, Datenhandbuch zur Geschichte des Deutschen Bundestages 1949 bis 1999. Band II (Berlin: Deutscher Bundestag, 1999), pp.1788-952.

20. Dishaw, 'Roll Call Vote Deviancy', p.541.

21. The total number does not refer to 1,659 different persons because many legislators served during more than one of the terms under study. On turnover in the relevant Bundestag elections see Philip Manow, 'Electoral Rules and Legislative Turnover: Evidence from Germany's Mixed Electoral System', West European Politics 30/1 (2007), p.197.

22. The data are taken from Peter Schindler, Datenhandbuch zur Geschichte des Deutschen Bundestages 1949 bis 1999. Band I (Berlin: Deutscher Bundestag, 1999), chap.5-6. We are grateful to Dominic Heinz for supplying us with this data.

23. Rueckert and Crane, 'CDU Deviancy', p.482. Beyond the German context, similar arguments have been made for the United Kingdom where paid and unpaid government members are expected to toe the party line in voting or resign their privileged positions ('payroll vote'; see Philip Norton, Parliament in British Politics (Houndmills: Palgrave Macmillan, 2005), p.56).

24. An analysis of the number of deviating explanations using count data regressions produces similar results. Also, clustering standard errors according to legislator produces the same substantive inferences.

25. For a similar measure, see Zittel and Gschwend, 'Individualisierte Wahlkämpfe', p.303. Data on the closeness of district races are taken from Statistisches Bundesamt, Wahlen zum 11. Deutschen Bundestag am 25. Januar 1987. Fachserie 1 Heft 5 (Mainz: Kohlhammer, 1987), pp.138-141; Statistisches Bundesamt, Wahlen zum 13. Deutschen Bundestag am 16. Oktober 1994. Fachserie 1 Heft 5 (Stuttgart: Metzler-Poeschel, 1994), pp.74-9.

26. As many party-list legislators also run in districts, they might face similar incentives to address local demands so that the difference between district and party-list legislators could be blurred. This contamination effect should be particularly relevant for legislators finishing second in the district. Empirically, we do not find support for this view in our data. When we analyse only legislators finishing second in the district and include the competitiveness variable in the model, we do not find a relationship between closeness of the district race and these legislators' propensity to defect from the party line.

27. See Saalfeld, Parteisoldaten und Rebellen, pp.233, 273-4.

28. For an analysis of the relationship between defection and re-election prospects of legislators in the Bundestag, see Saalfeld, Parteisoldaten und Rebellen, chap.12.

29. As further hypothesis, such defections tied to close electoral competition in the district should become more likely as elections approach. Unfortunately, we cannot test this hypothesis here, because our data are aggregated over entire electoral periods. 